\title{
Coordination, Fair Treatment and Inflation Persistence*
}

\author{
by \\ John C. Driscoll \\ Federal Reserve Board \\ Mail Stop 75 \\ $20^{\text {th }}$ and Constitution Avenue, NW \\ Washington DC 20551 \\ email:John_Driscoll@alum.mit.edu \\ homepage: http://www.johncdriscoll.net \\ and \\ Steinar Holden \\ University of Oslo and Norges Bank \\ Department of Economics, University of Oslo \\ Box 1095 Blindern, 0317 Oslo, Norway \\ email: steinar.holden@econ.uio.no \\ homepage: http://folk.uio.no/ sholden/
}

First draft: 28 March 2001

This version: 10 December 2002

\begin{abstract}
Most wage-contracting models with rational expectations fail to replicate the persistence in inflation observed in the data. We argue that coordination problems and multiple equilibria are the keys to explaining inflation persistence. We develop a wage-contracting model in which workers are concerned about being treated fairly. This model generates a continuum of equilibria (consistent with a range for the rate of unemployment), where workers want to match the wage set by other workers. If workers' expectations are based on the past behavior of wage growth, these beliefs will be self-fulfilling and thus rational. Based on quarterly U.S. data over the period 1955-2000, we find evidence that inflation is more persistent between unemployment rates of 4.7 and 6.5 percent, than outside these bounds, as predicted by our model.

Keywords: Inflation persistence, coordination problems, adaptive expectations. JEL Classification numbers: E31, E3, E5.

* The paper has benefited from comments by V. Bhaskar, Jeff Fuhrer, Greg Mankiw, Ian McDonald, Ragnar Nymoen, Andrew Oswald, and participants at seminars at Boston University, the Boston Fed, the University of Oregon, the Kiel Institute, the University of Oslo, Rutgers University and NBER Conferences on Macroeconomics and Individual Decision Making and on Monetary Economics. Steinar Holden is grateful to the NBER for its hospitality when most of this paper was written. The opinions expressed in this paper are those of the authors and do not necessarily reflect the views of the Board of Governors of the Federal Reserve System
\end{abstract}




\section{$1 \quad$ Introduction}

In recent years the short run aggregate supply curve has been the subject of renewed interest. Much of the theoretical literature has converged on a Taylor (1980) and Calvo (1983) type relationship, where nominal wage or price stickiness is combined with the assumption of rational expectations; the result is sometimes referred to as the New Keynesian Phillips curve. However, as has been pointed out by Fuhrer and Moore (1995) and more recently by Taylor (1999) and Mankiw (2000), these models run into serious problems when confronted with data: the models predict stickiness in prices, but not in inflation, and are thus unable to explain the inertia of actual inflation. Furthermore, as shown by Ball (1994), the models predict that anticipated disinflation is expansionary, which seems inconsistent with the experiences of many countries in the 1980s and 90s. Perhaps most intriguingly, Mankiw (2001) has observed that the models predict that a contractionary monetary shock causing a delayed and gradual decline in inflation should cause unemployment to fall during the transition, in stark contrast to the received wisdom of the effect of monetary contractions.

In short, macroeconomists are faced with the puzzle that the standard formulation of the short run aggregate supply curve seems to be an empirical failure. The search for a model that is both theoretically and empirically satisfying has led to a number of different suggestions, including among others near-rational expectation formation (Roberts, 1998, and Ball, 2000), slowly diffusing information (Mankiw and Reis, 2001), and on replacing the output gap with marginal costs (Gali and Gertler, 1999, and Sbordone, 2002; for a critique, see Bårdsen, Jansen and Nymoen, 2002). However, all these suggestions have their weaknesses, and it seems fair to say that the profession is still looking for a satisfying alternative. 
In this paper, we propose a new explanation for inflation persistence, based on coordination problems arising from the existence of a range of equilibrium output levels. In most existing price (or wage) setting models, while comparisons with other price setters are important to the individual price setter, these comparisons generate persistence in the level, but not the growth rate, of prices. We show that the existence of a range of equilibria opens up for a new vehicle of persistence that may also affect growth rates. With a range of equilibria, agents cannot deduce logically the future actions of other price setters from the assumption that they behave rationally. In this situation we argue that the past behavior of the price setters takes a prominent position as a focal point. More specifically, the past behavior of the price setters may work as an equilibrium selection device: among all the actions consistent with a possible equilibrium, agents expect other agents to play as they have played in the past.

The key requirement for these features is thus the existence of a range of equilibria for the economy. In the literature, a number of mechanisms generating a range of equilibria have been proposed; see the survey of theories and evidence in McDonald (1995). We focus on only one, following Bhaskar (1990). Specifically, we assume that workers are concerned about fair treatment, in the sense that they care disproportionately more about being paid less than other workers than they do about being paid more than other workers. When this assumption is incorporated in a standard wage bargaining model, the result is a continuum of rational expectations equilibria, in the form of a range of wage growth rates for which each wage setter will aim for the same wage growth as set by the others. Combining wage setting with the price setting behavior of firms, the range of possible rates of wage growth transforms into a range of equilibrium rates of 
output. Intuitively, if wage setters expect other wage setters to set a low nominal wage growth, each wage setter will follow the lead by the others and aggregate wage growth will be low. For a given level of nominal aggregate demand (determined by monetary policy), real aggregate demand and thus output will be high. On the other hand, if wage setters expect other wage setters to set a high money wage growth, they will also set a high wage growth. For given nominal aggregate demand, real aggregate demand and output will be low. ${ }^{1}$

However, outside the range of equilibria, the labor market is sufficiently tight or slack that it dominates workers' concern for fair treatment. If the labor market is too tight, workers will aim at higher wages than others; if labor market is too slack, workers must accept lower wages than others, and in both cases the continuum of equilibria collapses to a single point. With forward-looking agents, the model then resembles Taylor (1980)'s canonical formulation.

Note that while our assumption concerning worker preferences is key in our model, it could be replaced with other mechanisms generating a range of equilibria. For example, Woglom (1982) showed the existence of a range of equilibria in a customer market model, where a price rise has larger negative effect on demand than the positive effect of a price reduction of the same magnitude. In independent work, McDonald and Sibly (2001), discuss the effect of monetary policy in a model with a range of equilibria based on customer markets and worker loss aversion relative to past real wages. Our

${ }^{1}$ Bhaskar (1990) also derives a range of output equilibria based on similar assumptions on preferences (but within a different wage setting framework). He mentions that the continuum of equilibria may induce inertia in nominal wage growth, but does not pursue this idea. 
approach is also related to Lye, McDonald and Sibly (2001), where Phillips-curve like equations are derived based on an assumption of worker loss aversion. However, Lye, McDonald and Sibly do not focus on inflation persistence. Cooper (1999) surveys other macroeconomic models with a multiplicity of equilibria.

We confront the model with US quarterly data for unemployment and CPI inflation for the period 1955 -2000. The results are generally favorable. Consistent with our theory, we find that inflation is highly persistent, and that the relationship between inflation and unemployment is much noisier than standard theory would suggest. However, as these are well-known empirical results (emphasized by, for example, Staiger, Stock and Watson, 1997), their value as a test of our theory is limited. Consequently, the results concerning the novel predictions are more important. Again, the results are promising: The evidence supports the existence of bounds for the rate of unemployment, in line with our prediction that there is a range of equilibria, not a unique natural rate. There is also some support for the prediction that inflation will react strongly to output outside the range, as we find a strong increase in inflation for unemployment rates below the range. However, we do not find the corresponding strong decrease for high unemployment.

The paper is organized as follows: section 2 presents the model and describes the resulting dynamics of inflation; section 3 discusses the empirical implications and specification for the estimates; section 4 discusses the data used and empirical results; and section 5 concludes. 
We consider an economy consisting of $\mathrm{K}$ symmetric firms, each producing a different good. In each firm there are $\mathrm{L} / \mathrm{K}$ insiders, who bargain jointly with the firm over their wage. After the wage determination, each firm sets the price of its product, facing a downward sloping demand curve. All agents are fully aware of how the economy works, so they can predict what other agents will do at the same and later stages of the model.

Each firm $\mathrm{j}$ has a constant returns to scale production function $Y_{j t}=N_{j t}$, where $Y_{j t}$ is output, $\mathrm{N}_{\mathrm{jt}}$ is employment, and the $\mathrm{t}$ subscript indicates the time period. The real profits of the firm are

$$
\Pi_{\mathrm{jt}}=\left(\mathrm{P}_{\mathrm{jt}} \mathrm{Y}_{\mathrm{jt}}-\mathrm{X}_{\mathrm{jt}} \mathrm{N}_{\mathrm{jt}}\right) / \mathrm{P}_{\mathrm{t}}
$$

where $P_{j t}$ is the price of output, $X_{j t}$ is the nominal wage in firm $j$, and

$$
P_{t}=\left(\frac{1}{K} \sum_{j} P_{j t}^{1-\eta}\right)^{\frac{1}{1-\eta}} \quad \eta>1,
$$

is the aggregate price level. The demand function facing each firm has a constant elasticity

(3) $\mathrm{Y}_{\mathrm{jt}}=\left(\mathrm{P}_{\mathrm{jt}} / \mathrm{P}_{\mathrm{t}}\right)^{-\eta} \mathrm{Y}_{\mathrm{t}} / \mathrm{K}$, 
where $Y_{t}$ is aggregate output. ${ }^{2}$

We now turn to the payoff function of the workers. Following Bhaskar (1990) we assume that workers are concerned with fair treatment, and resent being treated worse than identical workers elsewhere. Furthermore, their dissatisfaction from being paid less than identical workers in other firms is greater than the benefit from being paid more. Formally, the utility function of the workers is non-differentiable at the wage level of other workers, so that the left-hand derivative is greater than the right-hand derivative.

There is considerable empirical support for an assumption of this kind. First, several experimental studies report asymmetric effects of pay differences on levels of satisfaction. Austin, McGinn and Susmilch (1980) employ a design in which subjects are randomly divided into three groups. In one group, the subjects read a story in which they are rewarded less pay than another identical worker; in the second, they receive equal pay; in the third, they receive more pay. The subjects are then asked to rate their satisfaction and fairness. The difference in satisfaction between the group paid more and the group paid equally is much smaller than the difference in satisfaction between the group paid equally and the group paid less. Ordonez, Connolly and Coughlan (2000) have subjects read a story in which a focal MBA graduate and one or two other comparison MBA graduates receive job offers. The number of comparison graduates and the salaries all three receive are varied across the subjects. The reported decrease in satisfaction when one of the comparison graduates has a higher offer is more than four times higher than the reported increase in satisfaction when one of the comparison graduates has a lower offer.

\footnotetext{
${ }^{2}$ Equation (3) can be derived by assuming Dixit-Stiglitz preferences; see Blanchard and
} 
Second, several studies report asymmetric aversion to inequity. Loewenstein, Thompson and Bazerman (1989) report that subjects show strong aversion against disadvantageous inequality; while many subjects also exhibit aversion to advantageous inequality, this effect seems to be significantly weaker than the aversion to disadvantageous inequality. Goeree and Holt (2000) document the existence of asymmetric inequality aversion in experiments of alternating offers bargaining. Fehr and Schmidt (1999) develop a theory of inequity aversion and show that it is able to explain a number of seemingly puzzling findings in different economic situations.

Third, our assumption is also in accord with experiments on loss aversion, by Kahneman and Tversky (1979) and others. These indicate that outcomes are not perceived neutrally; rather, the value function appears to be steeper for losses than for gains.

Finally, although for our results below we only require that workers have asymmetries in preferences and not outcomes (e.g. effort), it is worth noting that Akerlof (1984) reports that studies on the relationship between pay and effort generally find stronger evidence for the withdrawal of services by workers who think they are underpaid, than the positive effect on the effort of "overpaid" workers. ${ }^{3}$

Formally, we assume that the payoff function of a representative worker is

$$
\begin{aligned}
& V_{j t}=V\left(\frac{X_{j t}}{P_{t}}, \frac{X_{j t}}{X_{J t}}, \frac{X_{j t}}{X_{G t}}\right) \equiv \frac{X_{j t}}{P_{t}}\left(\frac{X_{j t}}{X_{J t}}\right)^{\alpha+D_{j i} \Phi}\left(\frac{X_{j t}}{X_{G t}}\right)^{\lambda} \\
& 0<\phi, \lambda<1,0<\alpha+\phi<1,
\end{aligned}
$$

Kiyotaki (1985) for an early implementation in a macroeconomic model of price setting. ${ }^{3}$ Danthine and Kurmann (2002) develop a sticky-wage model based on Akerlof's related partial gift exchange idea. 
where $\mathrm{X}_{\mathrm{Jt}}$ is the average wage of workers in the same group, $\mathrm{X}_{\mathrm{Gt}}$ is the average wage of workers in the other group, and $\mathrm{D}_{\mathrm{jt}}$ is a dummy variable being one if $\mathrm{X}_{\mathrm{jt}}<\mathrm{X}_{\mathrm{Jt}}$ and zero otherwise. The payoff is continuous in real and relative wages, and strictly increasing in the real wage. One would expect workers to prefer being paid more than others $(\alpha$ positive); however, for the sake of generality we also allow for the possibility that workers dislike inequality even if they gain themselves ( $\alpha$ negative). In any case (4) implies workers always prefer higher wages for given wages of others. The key assumption is that the payoff is assumed to be non-differentiable at the point where wages are equal to the wages of other workers in the same group, $\mathrm{X}_{\mathrm{jt}}=\mathrm{X}_{\mathrm{Jt}}$, so that the loss in payoff of a reduction in the relative wage is strictly greater than the gain in payoff of an increase in the relative wage. The non-differentiability only applies to workers in the same group, which could reflect that workers in different groups are different, so that the notion of equal wages for identical workers does not apply to workers in other groups. Note, however, that allowing the comparison to workers in other groups to be nondifferentiable would strengthen our results. It would also be straightforward to generalize the static results to $\mathrm{n}$ different groups.

With the exception of the non-differentiability assumption, the results are robust to plausible variations in preferences. Working hours are treated as fixed, and are not included. Employment is not included in (4), which could be justified by the assumption that insiders are always employed, as variation in employment is undertaken by the firm adjusting the hiring of new workers. However, the qualitative results would hold also if workers were concerned about employment, or if working hours were allowed to vary. 
Moreover, the qualitative results would not be affected if the payoff were an arbitrary strictly increasing function of the real wage, rather than a linear function.

In fact, the key features of the model are also robust to much more profound variations of the model assumptions. As noted by Bhaskar (1990), the particular assumptions concerning wage setting can be relaxed: qualitatively the same features can be derived under individual wage bargaining or efficiency wages effects. ${ }^{4}$

Returning to the model, it is well known that maximization of profits with a constant elasticity of demand implies that the price is set as a mark-up over the marginal cost (which is here simply the wage), that is, the first order condition of the profit maximization problem implies

$$
\mathrm{P}_{\mathrm{jt}}=\mu \mathrm{X}_{\mathrm{jt}}, \quad \text { where } \mu=\eta /(\eta-1)>1 .
$$

As profits are concave in $\mathrm{P}_{\mathrm{jt}}$, the first-order condition is sufficient to ensure a unique maximum, and the optimal price is independent of the price set by other firms. The indirect payoff function of the firm, as functions of the real wage and aggregate output, can be found by use of (1), (3), (5) and the production function $Y_{j t}=N_{j t}$.

$$
\Pi_{\mathrm{jt}}=\Pi\left(\mathrm{X}_{\mathrm{j} t} / \mathrm{P}_{\mathrm{t}}, \mathrm{Y}_{\mathrm{t}}\right)=(\mu-1)\left(\mathrm{X}_{\mathrm{jt}} / \mathrm{P}_{\mathrm{t}}\right)^{1-\eta} \mu^{-\eta} \mathrm{Y}_{\mathrm{t}} / \mathrm{K}
$$

\footnotetext{
${ }^{4}$ If there is uncertainty as to the wage of others, this will smoothen out any nondifferentiability and the results disappear. On the other hand, if there is a minimum unit of account, or if wage settlements focus on round amounts, the non-differentiability will re-emerge and our results still hold. For simplicity, we neglect both these complexities.
} 


\section{Wage setting}

Wage setting takes place simultaneously in all firms. Each firm is small so the wage setters in a single firm is assumed to take the values of the aggregate variables $X_{J t}, X_{t}, P_{t}$ and $\mathrm{Y}_{\mathrm{t}}$ as exogenous in the negotiations. However, the parties will take into consideration that the employment level depends on the wage level, as implied by (5) and (3).

We assume that the outcome of the wage negotiations is given by the Nash bargaining solution.

$$
X_{j t}=\arg \max \Omega_{j t}, \quad \text { where } \Omega_{j t}=\left[\Pi\left(\frac{X_{j t}}{P_{t}}, Y_{t}\right)-\Pi_{0}\right] \cdot\left[V\left(\frac{X_{j t}}{P_{t}}, \frac{X_{j t}}{X_{J t}}, \frac{X_{j t}}{X_{G t}}\right)-V_{0}\right]
$$

and subject to $\Pi \geq \Pi_{0}$ and $V \geq V_{0}$, and labor demand as implied by (5) and (3). As argued by Binmore, Rubinstein and Wolinsky (1986), the appropriate interpretation of the threat points of the parties depends on the force that ensures that the parties reach an agreement. We assume that if no agreement is reached (which will not happen in equilibrium), there is a risk that negotiations break down. Let $\mathrm{V}_{0 \mathrm{t}}=\mathrm{V}_{0}\left(\mathrm{Y}_{\mathrm{t}}\right)$ be the expected payoff of the workers in this event; higher aggregate output is associated with higher aggregate employment, and thus makes it easier for the workers to find a new job, increasing the expected payoff for job losers. The expected payoff of the firm in the case of a breakdown of the negotiation is for simplicity set to zero. Inserting $V_{0}=V_{0 t}$ and $\Pi_{0}=0$ in the Nash maximand, and taking into consideration the non-differentiability of the payoff function of the union, the first order conditions for the Nash bargain require that the leftand right-hand derivatives of the Nash maximand satisfy the following inequalities ${ }^{5}$

\footnotetext{
${ }^{5}$ To ensure existence of an interior solution, we must have that $\eta>2+\alpha+\phi+\lambda$.
} 


$$
\frac{d \Omega^{-}{ }_{j t}}{d X_{j t}}=\frac{d \Pi_{j t}}{d X_{j t}}\left(V_{j t}-V_{0 t}\right)+\Pi_{j t} \frac{d V^{-}}{d X_{j t}} \geq 0
$$

$$
\frac{d \Omega^{+}{ }_{j t}}{d X_{j t}}=\frac{d \Pi_{j t}}{d X_{j t}}\left(V_{j t}-V_{0 t}\right)+\Pi_{j t} \frac{d V^{+}}{d X_{j t}} \leq 0
$$

In addition to (8) and (9), we know that either $\mathrm{X}_{\mathrm{jt}}=\mathrm{X}_{\mathrm{Jt}}$, or (8) or (9) hold with equality.

Let $\mathrm{X}_{\mathrm{t}}^{-}=\mathrm{X}^{-}\left(\mathrm{X}_{\mathrm{Jt}}, \mathrm{X}_{\mathrm{Gt}}, \mathrm{Y}_{\mathrm{t}}, \mathrm{P}_{\mathrm{t}}\right)$ and $\mathrm{X}_{\mathrm{t}}^{+}=\mathrm{X}^{+}\left(\mathrm{X}_{\mathrm{Jt}}, \mathrm{X}_{\mathrm{Gt}}, \mathrm{Y}_{\mathrm{t}}, \mathrm{P}_{\mathrm{t}}\right)$ denote the wage levels $\mathrm{X}_{\mathrm{jt}}$ for which (8) and (9) respectively hold with equality. As shown in the appendix, we know that $\mathrm{X}^{-}\left(\mathrm{X}_{\mathrm{Jt}}, \mathrm{X}_{\mathrm{Gt}}, \mathrm{Y}_{\mathrm{t}}, \mathrm{P}_{\mathrm{t}}\right)>\mathrm{X}^{+}\left(\mathrm{X}_{\mathrm{Jt}}, \mathrm{X}_{\mathrm{Gt}}, \mathrm{Y}_{\mathrm{t}}, \mathrm{P}_{\mathrm{t}}\right)$. Furthermore, in the appendix we also show the following result

Result 1: There exists a unique outcome $X_{\mathrm{jt}}$ to the wage bargaining in firm $\mathrm{j}$, given by
(i) If $\quad \mathrm{X}_{\mathrm{Jt}}>\mathrm{X}_{\mathrm{t}}^{-}$; $\mathrm{X}_{\mathrm{jt}}=\mathrm{X}_{\mathrm{t}}^{-}$
(ii) If $\mathrm{X}_{\mathrm{Jt}} \in\left[\mathrm{X}_{\mathrm{t}}^{+}, \mathrm{X}_{\mathrm{t}}^{-}\right]$ $\mathrm{X}_{\mathrm{jt}}=\mathrm{X}_{\mathrm{Jt}}$
(iii) If $\mathrm{X}_{\mathrm{Jt}}<\mathrm{X}_{\mathrm{t}}^{+}$;
$\mathrm{X}_{\mathrm{jt}}=\mathrm{X}_{\mathrm{t}}^{+}$

The intuition is in fact fairly simply. If the average wage in the group is within the range $\left[\mathrm{X}_{\mathrm{t}}^{+}, \mathrm{X}_{\mathrm{t}}^{-}\right]$, the wage setting in firm $\mathrm{j}$ will match this wage. However, if the average wage in the group is higher than the upper boundary $\mathrm{X}_{\mathrm{t}}^{-}$, workers in firm $\mathrm{j}$ are not able to match this wage, but they are able to obtain a "high" wage $\mathrm{X}_{\mathrm{t}}^{-}$because of the high marginal utility of wages when they have lower wages than the rest of the group. If the average wage in the group is below the lower boundary $\mathrm{X}^{+}$, workers in firm $\mathrm{j}$ will obtain more 
than the average wage in the group, but they nevertheless only obtain a "low" wage $\mathrm{X}_{\mathrm{t}}^{+}$ because of the low marginal utility of wages when they have higher wages than average.

In a symmetric equilibrium within each group, all wage setters in the same group set the same wage, thus we can focus on case (ii) of Proposition 1 where $\mathrm{X}_{\mathrm{jt}}=\mathrm{X}_{\mathrm{Jt}}{ }^{6} \mathrm{We}$ set $\mathrm{X}_{\mathrm{jt}}=\mathrm{X}_{\mathrm{Jt}}$ in (8) and (9), and take into consideration that firms set prices as a markup over wages as given from (5) by imposing $\mathrm{P}_{\mathrm{t}}=\mu\left(\mathrm{X}_{\mathrm{Jt}}\right)^{1 / 2}\left(\mathrm{X}_{\mathrm{Gt}}\right)^{1 / 2}$. Letting lower case letters denote logs, (8) and (9) can be rewritten as

(11) $x_{J t} \geq x_{G t}-\theta^{+}+\frac{\gamma_{0}}{2} y_{t}$

where the threat point $\mathrm{V}_{0}\left(\mathrm{Y}_{\mathrm{t}}\right)$ is approximated by a log linear function, and $\theta^{+}, \theta^{-}$and $\gamma_{0}$ are positive parameters, where $\theta^{+}>\theta^{-}$; see the appendix for a detailed derivation. Equations (10) and (11) can be used to derive bounds for output that must be satisfied in an overall symmetric equilibrium, where the same wage is set for both groups. Setting $\mathrm{x}_{\mathrm{Jt}}$ $=\mathrm{x}_{\mathrm{Gt}}$ and imposing equality in (10) and (11), we can solve for $\mathrm{y}_{\mathrm{t}}=2 \theta^{-} / \gamma_{0} \equiv \mathrm{y}^{\mathrm{L}}$ and $\mathrm{y}_{\mathrm{t}}=$ $2 \theta^{+} / \gamma_{0} \equiv \mathrm{y}^{\mathrm{H}}>\mathrm{y}^{\mathrm{L}}$. It is then immediate that (10) and (11) are satisfied for any $\mathrm{x}_{\mathrm{Jt}}=\mathrm{x}_{\mathrm{Gt}}$ if and only if $\mathrm{y}_{\mathrm{t}} \in\left[\mathrm{y}^{\mathrm{L}}, \mathrm{y}^{\mathrm{H}}\right]$. It turns out that any output level in this range is consistent with an overall symmetric equilibrium in the model.

\footnotetext{
${ }^{6}$ As discussed by Bhaskar (1990), we cannot be sure that a symmetric equilibrium will be realized. We discuss this below.
} 
The intuition for the range of equilibrium output levels is based on the feature that the range of equilibrium wage levels in Result 1 is transformed into a range for output. As long as output is within the range $\left[\mathrm{y}^{\mathrm{L}}, \mathrm{y}^{\mathrm{H}}\right]$, workers in any individual firm are in a position to obtain the same wage as workers in other firms; no more and no less. Output above $\mathrm{y}^{\mathrm{H}}$ is not consistent with equilibrium, because then all workers would be in a stronger position in the wage setting and they would all obtain higher wages than the others, which is clearly impossible (formally, $\mathrm{y}_{\mathrm{t}}>\mathrm{y}^{\mathrm{H}}$ would imply that $\mathrm{x}_{\mathrm{Jt}}>\mathrm{x}_{\mathrm{Gt}}$ from (11), thus violating the symmetric equilibrium condition $\mathrm{x}_{\mathrm{Jt}}=\mathrm{x}_{\mathrm{Gt}}$ ). Analogously, output below $\mathrm{y}^{\mathrm{L}}$ would imply that all workers would get lower wages than the others, which is also impossible.

Note that the existence of a range depends on the non-differentiability parameterized by $\phi$. If $\phi=0$, so that the left- and right-hand derivatives (8) and (9) are equal, the range for wages in Proposition 1 would collapse to a single point. Likewise, $\phi=0$ would imply that $\theta^{-}=\theta^{+}$, implying that $\mathrm{y}^{\mathrm{L}}=\mathrm{y}^{\mathrm{H}}$ so that output is uniquely determined.

To complete the model, we also need to specify the demand side of the economy. For simplicity, we assume that aggregate demand (equal to aggregate output in equilibrium) is given by the quantity equation

(12) $y_{t}=m_{t}-p_{t}$

where the nominal money stock $\mathrm{m}_{\mathrm{t}}$ is set by the central bank, prior to the wage and price setting. ${ }^{7}$ For completeness, we include the price level in logs as

\footnotetext{
${ }^{7}$ As with equation (3), this is a standard result in models with Dixit-Stiglitz preferences over consumption goods and either a cash-in-advance constraint or real balances in the utility function. See Blanchard and Kiyotaki (1985) for one derivation.
} 


$$
\mathrm{p}_{\mathrm{t}}=\ln (\mu)+1 / 2\left(\mathrm{x}_{\mathrm{Jt}}+\mathrm{x}_{\mathrm{Gt}}\right)
$$

An (overall) symmetric equilibrium, where the same wage is set for both groups, is a quadruple $\left(\mathrm{x}_{\mathrm{Jt}}, \mathrm{x}_{\mathrm{Gt}}, \mathrm{y}_{\mathrm{t}}, \mathrm{p}_{\mathrm{t}}\right)$ that satisfies: $\mathrm{x}_{\mathrm{Jt}}=\mathrm{x}_{\mathrm{Gt}}, \mathrm{x}_{\mathrm{Jt}}$ satisfies (10) and (11) (ensuring that the wage maximises the Nash bargaining solution, and implying that $\mathrm{x}_{\mathrm{Gt}}$ is within a similar interval), prices are set to maximise profits (as given by (13)), and finally the aggregate demand function (12).

The equilibrium of the overall economy can be summarized in the following result (Bhaskar, 1990, derives a similar result).

Result 2: For a given value of the nominal money stock $\mathrm{m}_{\mathrm{t}}$, there exists a range of overall symmetric equilibria to the economy, as characterized as follows. Let $x^{L}{ }_{t}=m_{t}-\ln (\mu)-y^{L}$ and $\mathrm{x}^{\mathrm{H}}{ }_{\mathrm{t}}=\mathrm{m}_{\mathrm{t}}-\ln (\mu)-\mathrm{y}^{\mathrm{H}}$, where $\mathrm{x}_{\mathrm{t}}^{\mathrm{H}}<\mathrm{x}_{\mathrm{t}}^{\mathrm{L}}$. Then any wage level $\mathrm{x}_{\mathrm{t}}$ in the interval $\left[\mathrm{x}^{\mathrm{H}}, \mathrm{x}^{\mathrm{L}}{ }_{\mathrm{t}}\right]$ is a symmetric perfect forecast equilibrium, with associated output level $y_{t}=m_{t}-\ln (\mu)$ $\mathrm{x}_{\mathrm{t}}$ in the interval $\left[\mathrm{y}^{\mathrm{L}}, \mathrm{y}^{\mathrm{H}}\right]$.

Note that the equilibria are Pareto rankable, as profits and employment are increasing in output, whereas the real wage is independent of output (from (13), $x_{t}-p_{t}=-\ln (\mu)$ ). Thus, some agents gain from higher output, whereas no agents lose from higher output. However, in a large economy with a vast number of small agents, it is not clear that agents will be able to coordinate on the best equilibrium. If some agents set low wages 
$\mathrm{x}^{\mathrm{H}}$ to ensure the Pareto optimal equilibrium with $\mathrm{y}^{\mathrm{H}}$, they run the risk of getting lower wages than others, with associated loss of utility.

An interesting possible solution to the coordination problem would apply if one had a fully credible price or inflation target (see also McDonald and Sibly, 2001). If the central bank could credibly announce a price target $\mathrm{p}^{\mathrm{E}}$, ensuring that all agents indeed expected $\mathrm{p}^{\mathrm{E}}$ to be realized, the Pareto optimal, high employment equilibrium could be realized by setting $\mathrm{m}=\mathrm{y}^{\mathrm{H}}-\mathrm{p}^{\mathrm{E}}$. However, in the sequel we will focus attention on a situation without a credible price or inflation target.

\section{Overlapping wage contracts}

Now consider an overlapping contracts version of the model: Each group set wages for two periods, one group in odd periods and the other in even periods, as in the standard Taylor model. ${ }^{8}$ Let $\mathrm{x}_{\mathrm{t}}$ denote the wage set in period t. The constraints derived from the wage setting now reads (replacing $\mathrm{x}_{\mathrm{Gt}}$ with $\left(\mathrm{x}_{\mathrm{t}-1}+\mathrm{E}_{\mathrm{t}} \mathrm{x}_{\mathrm{t}+1}\right) / 2$ in (10) and (11), as well as using the definitions of $\mathrm{y}^{\mathrm{L}}$ and $\mathrm{y}^{\mathrm{H}}$. Note that even forward-looking agents will not take the dynamic link between the wages of the groups into consideration in firm level wage bargaining, as each firm is too small to affect the wage of the group as a whole)

$$
\begin{aligned}
& x_{t} \leq \frac{1}{2}\left(x_{t-1}+E_{t} x_{t+1}\right)+\frac{\gamma_{0}}{2}\left(y_{t}-y^{L}\right) \\
& x_{t} \geq \frac{1}{2}\left(x_{t-1}+E_{t} x_{t+1}\right)+\frac{\gamma_{0}}{2}\left(y_{t}-y^{H}\right)
\end{aligned}
$$

${ }^{8}$ Similar results could be derived in a more realistic, but also more cumbersome model where the non-differentiability only applies relative to a subset of the workers setting their wage at the same time. 
(14) and (15) can be rewritten as constraints on the nominal wage growth

$$
\begin{aligned}
& \Delta x_{t} \leq E_{t} \Delta x_{t+1}+\gamma_{0}\left(y_{t}-y^{L}\right) \\
& \Delta x_{t} \geq E_{t} \Delta x_{t+1}+\gamma_{0}\left(y_{t}-y^{H}\right)
\end{aligned}
$$

\section{Expectation formation}

As before, the wage and price setting do not uniquely pin down the dynamics of output and inflation. Although Equations (16) and (17) restrict wage growth to lie between bounds, the multiplicity of equilibria implies that, otherwise, both output and inflation depend on workers' expectations. This implies that agents cannot deduce other agents' behavior logically from the assumption that they behave rationally. In this situation it seems reasonable to assume that agents base their beliefs regarding wage growth on the past behavior of wage growth. This basic premise is common to a variety of approaches to expectation formation. Evans and Honkapohja (2001) advocate adaptive learning as a selection mechanism in situations with multiple rational expectations equilibria. Experiments on games with a multiplicity of equilibria also show that agents learn from the past behavior of other agents (Ochs, 1995). At the more general level, observing other people's behavior and making inferences on this basis is indeed how we form expectations about other people's behavior every day. If agents share this way of forming expectations, it will work as a focal point or coordination mechanism for agents' expectations. 
Consider the following wage equation, representing a stylized version of existing empirical wage equations

$$
\Delta \mathrm{x}_{\mathrm{t}}=\beta \Delta \mathrm{x}_{\mathrm{t}-1}+(1-\beta) \Delta \mathrm{x}_{\mathrm{t}-2}+\gamma_{1}\left(\mathrm{y}_{\mathrm{t}-1}-\mathrm{y}^{*}\right), \quad \gamma_{1}>0 .
$$

(For convenience, we specify (18) to only include two lags, but will allow for more lags in the empirical work.) Assuming that agents have observed wage inflation to adhere to (18) in the past, it seems reasonable that they would expect wage inflation to follow (18) in the future also, as long as this is consistent with the rational expectations equilibrium of the model, ie. it satisfies the constraints given by (16) and (17). In other words, (18) would work as a focal point for the wage setting behavior. Given that agents have these beliefs, they would be self-fulfilling and thus both ex ante and ex post rational. In a situation where agents set wages on the basis of (18), realization of another equilibrium would require all agents to simultaneously switch to a different behavior. If one disregards such simultaneous switches, the unique equilibrium outcome in this situation would be that agents continue to set wages according to (18).

Note also that if a share, however small, of the agents in the economy has adaptive expectations according to (18), this will serve as a coordination mechanism so that (18) is the unique strategy consistent with rational expectations (as also observed by Bhaskar, 1990).

Given (18), $\mathrm{y}^{*}$ is the unique long run equilibrium rate of output. Output cannot remain above or below $\mathrm{y}^{*}$, as this would lead to consistently increasing or decreasing nominal wage growth. Note however that $\mathrm{y}^{*}$ is inherently expectations based. $\mathrm{y}^{*}$ should not be interpreted as the natural rate as given by other considerations like search behavior 
or efficiency wages; the equivalent to these considerations are already captured in the model described in Result 2, which had a range of equilibria. If agents' expectations change, for instance they believe that the labor market has changed so that stable nominal wage growth is consistent with higher output $\mathrm{y}^{* *}$ rather than $\mathrm{y}^{*}$, this would imply a change in the long run equilibrium to the new level $\mathrm{y}^{* *}$, as long as $\mathrm{y}^{* *}$ is within $\left[\mathrm{y}^{\mathrm{L}}, \mathrm{y}^{\mathrm{H}}\right]$.

The important role of expectations in determining $\mathrm{y}^{*}$ suggests that one cannot expect to find a stable relationship between output and inflation. And this is indeed the case: Staiger, Stock and Watson (1997) find considerable imprecision in the estimates of the natural rate, and there has been considerable debate over the last decade in the U.S. over whether the decline in unemployment without a corresponding rise in inflation is evidence of a decrease in the natural rate. This noisy behavior is, however, consistent with our story. The structure of the labor market, and of price and wage setting, do not pin down a tight relationship between inflation and unemployment. In our model, expectations play a large role, and one is less surprised to find more noise and fluctuations, because expectations are likely to be more volatile than other features like preferences and technology.

The implications of the adaptive expectations focal point relationship (18) are well-known; the key novelties in this paper are the implications of the constraints (16) and (17). It turns out the existence of these constraints makes the model highly complex when agents are forward-looking. To evaluate whether the constraints bind, agents need to not only know the current money stock, but also to form expectations of the entire future path of monetary policy. 
To explore the implications of the bounds, consider first a temporary positive money shock, implying that (17) binds in one period, while agents expect the future wage inflation to follow (18). $\mathrm{E}_{\mathrm{t}} \Delta \mathrm{x}_{\mathrm{t}+1}$ can be derived by leading (18) one period

$$
\mathrm{E}_{\mathrm{t}} \Delta \mathrm{x}_{\mathrm{t}+1}=\beta \Delta \mathrm{x}_{\mathrm{t}}+(1-\beta) \Delta \mathrm{x}_{\mathrm{t}-1}+\gamma_{1}\left(\mathrm{y}_{\mathrm{t}}-\mathrm{y}^{*}\right)
$$

Substituting out for (19) in (17), and rearranging, we obtain

$$
\Delta x_{t} \geq \beta \Delta x_{t}+(1-\beta) \Delta x_{t-1}+\gamma_{1}\left(y_{t}-y^{*}\right)+\gamma_{0}\left(y_{t}-y^{H}\right)
$$

or

$$
\text { (21) } \Delta x_{t} \geq \Delta x_{t-1}+\frac{\gamma_{1}}{1-\beta}\left(y_{t}-y^{*}\right)+\frac{\gamma_{0}}{1-\beta}\left(y_{t}-y^{H}\right)
$$

Comparing (21) and (18), we note that the coefficient in front of output (i.e. the total of the two terms) is considerably larger in (21). Thus, when the bounds bind because a temporary positive money shock takes the economy above the static upper bound $\mathrm{y}^{\mathrm{H}}$, the effect of output on wage growth is much stronger than it is within the bounds, where wage inflation follows the adaptive focal point behavior as represented by (18).

Second, the bounds can bind because of an expected future monetary expansion. To see this as simply as possible, assume that agents expect the positive money shock to take place in period $t+1$. Leading (21) one period, we see that this will imply that agents expect high wage inflation in period $t+1$. For a sufficiently large expected positive money shock in period $t+1$, expected wage inflation in period $t+1$ will be sufficiently large that 
the constraint (17) binds already in period $t$, even if no positive monetary shock has taken place in that period. The implication will be that wage growth increases, raising prices, thus involving a contractionary effect as money growth has yet to increase in period t.

Likewise, an anticipated future monetary tightening, taking place when the economy is close to the lower output bound $\mathrm{y}^{\mathrm{L}}$, will imply that (16) binds and dampens wage growth, with a temporary expansionary effect. In fact, the immediate effects of an expected future monetary tightening correspond to the expansionary effect of a disinflation shown by Ball (1994) to be a prediction of the Taylor model. Note however that this effect only takes place under much more restrictive circumstances than in the Taylor model. In the Taylor model an anticipated future monetary tightening will induce output to exceed its equilibrium level. Here, the temporary expansionary effect only takes place when the monetary tightening is expected to subsequently take output down to the lower bound. Thus, this effect does not prevent that the overall effect of the monetary tightening is to induce a recession.

More generally, the existence of the bounds (16) and (17) implies that whenever they bind, variation in expected future wage inflation will induce variation in current inflation. In these cases, inflation will not be determined by the persistent and adaptive behavior specified in equation (18), but will fluctuate with changes in expected future inflation, caused, for example, by expected changes in future monetary policy. Empirically, we would consequently expect inflation to be less persistent outside the bounds.

In sum, we expect to see a Phillips curve which:

- implies inflation persistence for moderate levels of unemployment 
- implies stronger effects of monetary policy at low or high levels of unemployment than for intermediate levels of unemployment

- implies less inflation persistence and has a different slope for low and high levels of unemployment

\section{$3 \quad$ Empirical Specification}

To test the predictions, we adopt a levels version of Staiger, Stock and Watson (1997)'s specification:

$$
\begin{aligned}
\pi_{\mathrm{t}}= & \alpha_{0}+\alpha_{1} \pi_{\mathrm{t}-1}+\alpha_{2} \pi_{\mathrm{t}-2}+\alpha_{3} \pi_{\mathrm{t}-3}+\beta_{1} \mathrm{u}_{\mathrm{t}-1}+\beta_{2} \mathrm{u}_{\mathrm{t}-2}+\gamma \mathrm{Z}_{\mathrm{t}} \\
& +\alpha^{\mathrm{H}}{ }_{0} \mathrm{I}^{\mathrm{H}}+\alpha^{\mathrm{H}}{ }_{1} \mathrm{I}^{\mathrm{H}} \pi_{\mathrm{t}-1}+\alpha^{\mathrm{H}}{ }_{2} \mathrm{I}^{\mathrm{H}} \pi_{\mathrm{t}-2}+\alpha^{\mathrm{H}}{ }_{3} \mathrm{I}^{\mathrm{H}} \pi_{\mathrm{t}-3} \\
& +\beta^{\mathrm{H}}{ }_{1} \mathrm{I}^{\mathrm{H}}\left(\mathrm{u}_{\mathrm{t}-1}-\mathrm{u}^{\mathrm{H}}\right)+\beta^{\mathrm{H}}{ }_{2} \mathrm{I}^{\mathrm{H}}\left(\mathrm{u}_{\mathrm{t}-2}-\mathrm{u}^{\mathrm{H}}\right)+\gamma^{\mathrm{H}} \mathrm{I}^{\mathrm{H}} \mathrm{Z}_{\mathrm{t}} \\
& +\alpha^{\mathrm{L}}{ }_{0} \mathrm{I}^{\mathrm{L}}+\alpha^{\mathrm{L}}{ }_{1} \mathrm{I}^{\mathrm{L}} \pi_{\mathrm{t}-1}+\alpha^{\mathrm{L}}{ }_{2} \mathrm{I}^{\mathrm{L}} \pi_{\mathrm{t}-2}+\alpha^{\mathrm{L}}{ }_{3} \mathrm{I}^{\mathrm{L}} \pi_{\mathrm{t}-3} \\
& +\beta^{\mathrm{L}}{ }_{1} \mathrm{I}^{\mathrm{L}}\left(\mathrm{u}_{\mathrm{t}-1}-\mathrm{u}^{\mathrm{L}}\right)+\beta^{\mathrm{L}}{ }_{2} \mathrm{I}^{\mathrm{L}}\left(\mathrm{u}_{\mathrm{t}-2}-\mathrm{u}^{\mathrm{L}}\right)+\gamma^{\mathrm{L}} \mathrm{I}^{\mathrm{L}} \mathrm{Z}_{\mathrm{t}}+\varepsilon_{\mathrm{t}},
\end{aligned}
$$

where $\pi_{\mathrm{t}} \equiv \mathrm{p}_{\mathrm{t}}-\mathrm{p}_{\mathrm{t}-1}, \mathrm{I}^{\mathrm{H}}$ is a dummy variable taking the value 1 when $\mathrm{u}>\mathrm{u}^{\mathrm{H}}, \mathrm{I}^{\mathrm{L}}$ is a dummy variable taking the value 1 when $\mathrm{u}<\mathrm{u}^{\mathrm{L}}$, and $\mathrm{Z}$ represents a vector of proxies for aggregate supply shocks. Following common practice we have invoked an Okun's Law relationship to replace output with unemployment. This has the advantage that it is not necessary to make assumptions concerning the stationarity of output. The interaction of the dummy variables with the inflation and unemployment terms above and below the bounds allows us to test the model's prediction that the short-run dynamics of inflation and unemployment differ for low and high levels of unemployment. 
Aside from the inclusion of interaction terms to allow inflation dynamics to change outside the bounds, we depart from Staiger, Stock and Watson (1997) in two ways. First, as noted above, we write the equation in levels; this allows us to more easily compare our results with previous estimates of the Phillips curve and evaluate the behavior of inflation persistence. Second, we do not explicitly attempt to estimate a timevarying natural rate of unemployment. ${ }^{9}$ While there in general is reason to believe that parameters change over time, allowing for a time-varying natural rate in addition to the bounds would presumably be to ask for too much from the data.

We include supply shock variables for two related reasons. First, they represent deviations from the inflationary dynamics implied by the other coefficients in the model, and thus need to be controlled for to prevent omitted variable bias. Second, in principle equation (22) represents only one equation in a two-equation system (the other equation being the aggregate demand curve with unemployment substituted for output). OLS estimates of (22) will therefore suffer from simultaneous equations bias. The bias in estimating the aggregate supply coefficients will depend on the relative variance of the aggregate supply shocks to the aggregate demand shocks. By trying to proxy for the largest aggregate supply shocks, we reduce the variance of the unexplained portion of the aggregate supply shocks, and thus reduce the amount of the bias. ${ }^{10}$

The bounds, $\mathrm{u}^{\mathrm{H}}$ and $\mathrm{u}^{\mathrm{L}}$ as derived from $\mathrm{y}^{\mathrm{H}}$ and $\mathrm{y}^{\mathrm{L}}$, are determined by structural parameters of the model, including how the threat point depends on output and the size of

\footnotetext{
${ }^{9}$ Although the presence of the interaction terms between the dummy variables and constants does implicitly allow for this possibility during time of high and low unemployment.

${ }^{10}$ An alternative but complementary approach would be to estimate (22) via instrumental variables using an instrument for exogenous variations in aggregate demand or supply.
} 
the kink in preferences. Although in principle one could calibrate the size of the bounds, or, more simply, the size of $y^{\mathrm{H}}-\mathrm{y}^{\mathrm{L}}$ by picking values for the parameters, it is not clear what reasonable values for some of the parameters are. Were the bounds known, (22) would be estimable via OLS. Although they are not known, it is possible to estimate them endogenously. We follow the structural break literature ${ }^{11}$ by reestimating (25) for different values of $\mathrm{u}^{\mathrm{H}}$ and $\mathrm{u}^{\mathrm{L}}$ and picking the specification yielding the highest value for the log-likelihood.

\section{$4 \quad$ Data and Estimation Results}

We use the unemployment rate for all civilians age 16 and over, seasonally adjusted, monthly, and the CPI for all urban consumers, seasonally adjusted, monthly. ${ }^{12} \mathrm{We}$ average the data to obtain quarterly figures, and construct an inflation measure by multiplying the percent change in the CPI by 400 .

Following Ball and Mankiw (1995), ${ }^{13}$ we use three supply shock measures:

\footnotetext{
${ }^{11}$ See Quandt (1958) and Maddala and Kim (1998)

${ }^{12}$ We have also tried the demography-adjusted unemployment rates created by Shimer (1998), which captures the idea that the natural rate of unemployment may change over time due to changes in demographic variables (since the young are more likely to be unemployed than the old). The coefficient estimates were generally little changed, and the fit in terms of adjusted R squared worse, so we stick to the model with the ordinary unemployment series.

${ }^{13}$ We choose these measures of food and energy aggregate supply shocks rather than the alternative, also PPI-based, measures used in Staiger, Stock and Watson (1997) because the energy price measure used there has become significantly more volatile and highly negatively autocorrelated since 1995, suggesting a change in definition of the series.
} 
1. FOOD, constructed by taking the difference in inflation rates between the processed foods and feeds component of the PPI (series 1300) and PPI inflation

2. FUEL, constructed by taking the difference in inflation rates between the fuel and energy component of the PPI (series 1100) and PPI inflation

3. NIXON, a dummy for the wage and price controls in the Nixon and Ford administrations introduced by Gordon (1990).

We begin the sample in 1955:I, avoiding the effects of wage and price controls imposed during the Korean War, and we end it in 2000:IV.

Table 1 provides the main empirical results. The first column of Table 1 reports the results of estimating (22) without any bounds. The coefficients on unemployment alternate in sign but do sum to -.213 , so that the Phillips curve is downward sloping, as one would hope. Also as expected, the coefficients on lagged inflation are all positive and sum to 1.004 , implying inflation is persistent.

The next three columns report the results of imposing the bounds, endogenously determined by the method described above. The first column reports the coefficients on output, inflation and the supply shocks between the bounds, the next columns the additional effects below and above the bounds. We find the bounds to be at 4.7 and 6.5 percent, which correspond to (approximately) the $30^{\text {th }}$ and $70^{\text {th }}$ percentiles of observed unemployment. ${ }^{14}$ Note that the more elaborate specification allowing all coefficients to

\footnotetext{
${ }^{14}$ Since our technique may also pick up any possible non-linearity in the Phillips curve, we restrict the bounds to lie above and below the median value of unemployment observed. If we relax this restriction, the estimated bounds lie at 9.9 and 10.1 percent, the third-highest and second-highest unemployment rates observed.
} 
take different values outside the bounds, as predicted by our model, is supported by the data, as the restrictions that are involved by the regression without bounds (column 1) is rejected in a likelihood ratio test at the one percent level.

The third and fourth columns report the interaction terms describing how the coefficients change outside the bounds. First, note that the coefficients on the lagged inflation interaction terms are almost all negative- implying that inflation is less persistent both below and above the bounds, as predicted by our model. Below the bounds, the interaction terms sum to -.775 and above to -.453 , which are large in magnitude and statistically significant.

Below the bounds, the interaction terms on unemployment sum to -1.378 , implying that the Phillips curve is more steeply sloped, as predicted by our model. Above the bounds, however, the unemployment terms sum to .587 , which is close in magnitude to the value of .608 estimated between the bounds, implying a nearly-flat Phillips curve above the bound (although highly imprecisely determined), in contrast to the predictions of our model.

Table 2 evaluates the prediction that the effect of contractionary and expansionary monetary policy disturbances are different outside and between the bounds; one set shifts the Phillips curve, the other represents shifts along the Phillips curve. We use the measure of monetary policy derived by Bernanke and Mihov (1998) from a structural VAR model of the Federal Funds market. This measure essentially purges endogenous policy movements from the Federal Funds rate. From that variable, we construct a series consisting only of contractionary changes in policy and a series consisting only of expansionary changes. The variable is defined only over the period from 1966 to 1996 , 
where the starting date is determined by the change of the Federal Reserve's policy instrument to the Federal Funds rate. For dates outside those years, we set the value for the contractionary and expansionary variables to zero.

The first column reports results not imposing any bounds; monetary expansions have a small and statistically insignificant effect, while monetary contractions have a larger and statistically significant negative effect.

The remaining two columns report the results imposing the bounds. The bounds are estimated to be at unemployment rates of 4.7 and 6.5 , unchanged from Table 1; the coefficients on lagged inflation and unemployment are also not much changed. The results are largely consistent with our model: monetary policy expansions have a more positive effect outside the bounds (although significant only for high unemployment), while monetary contractions have a significant negative effect for high unemployment.

\section{$5 \quad$ Conclusion}

Standard rational-expectations formulations of the aggregate supply curve, such as those of Fischer (1978), Taylor (1980) and Calvo (1983) are unable to replicate the persistence of inflation observed in the data. We suggest that coordination problems and multiple equilibria are the keys to explaining inflation persistence. When there is a range of possible equilibria, there is scope for past behavior to play a role as an equilibrium selection device. Several possible mechanisms can generate a range of equilibria; we focus on a wage-contracting model in which (following Bhaskar, 1990) workers care disproportionately more about being paid less than other workers than they do about being paid more than other workers. We argue that as wage setters want to match the 
wage growth set by others, the behavior of wages in the recent past will be a natural starting point for expectations. Within the range of equilibria, such beliefs will create a self-fulfilling prophecy; and thus be consistent with rational expectations. These beliefs will combine the attractive features of both adaptive and rational expectations; they will be consistent with key features on actual inflation series, while at the same time not being based on agents making systematic errors.

Replacing output with unemployment, we estimate the model, including the bounds, on quarterly data over the period $1955-2000$. We find that the dynamics of the Phillips curve do change at unemployment rates below 4.7 percent and above 6.5 percent. As predicted by our model, inflation seems less persistent outside the bounds. The prediction that inflation is more sensitive to changes in unemployment outside the bounds receives mixed results: we find stronger effects for low unemployment, but not for high unemployment. We also find that monetary policy contractions and expansions shift the position of the Phillips curve outside the bounds, as predicted by our model (but only significant for monetary contractions for high levels of unemployment).

At the more general level our story is easier to reconcile with the rather erratic relationship between inflation and unemployment that exists in the data than more traditional models. In such models, the erratic behavior is often explained as arising from a time-varying NAIRU. However, a problem with this explanation is that attempts to identify the structural determinants of the NAIRU are generally disappointing (see, for example, Staiger, Stock and Watson, 2001). In our model, expectations play a large role, and one is less surprised to find more noise and fluctuations, as expectations may well be more volatile than other features like preferences and technology. 
We view our evidence as supportive of the existence of a range of equilibria for unemployment, and inflation being less persistent outside this range. However, as our evidence is based on inflation and unemployment, it can clearly not discriminate between our story of fair treatment, and possible other stories also generating the same macroeconomic characteristics.

In our model, inflation persistence is generated as a focal point for agents' expectations, and it is not an inherent feature derived from preferences and technology. This implies that inflation persistence may weaken or disappear if another focal point becomes more prominent. Indeed, Ball (2000) showed that in the period from 1879 through 1914, when the US had a gold standard, the price level was close to a random walk, implying that inflation is white noise. During this period, an even simpler expectation formation than the one presented here may be the most appropriate, namely that expected inflation was close to a constant (Ball, 2000).

In recent years, a possible candidate for a focal point for inflation expectations would be the inflation target of the central bank. If agents believe that the central bank will fulfill its inflation target, this can work as a coordinating device for expectations, as long as output remains without the equilibrium range. Somewhat speculatively, this suggests the following interpretation of why the high growth and falling unemployment in the US in the late 1990s did not lead to increasing inflation: the Federal Reserve commanded high credibility so that private agents expected the low inflation to continue, and thus set wages and prices according to this premise.

The use of preferences exhibiting loss aversion or other departures from standard assumptions has become commonplace in the study of consumption and asset pricing, 
and has been used to attempt to explain various empirical puzzles in those literatures. In this paper, we take a step towards applying preferences taken from behavioral economics to explain the empirical puzzle in the Phillips curve literature of inflation persistence. We show that a relatively minor departure from standard assumptions not only yields inflation persistence, but also sheds light on why the relationship between output and inflation is noisy and erratic. 


\section{References}

Akerlof, George (1984). "Gift Exchange and Efficiency Wage Theory: Four Views." American Economic Review Papers and Proceedings, 74, pp 79-83.

Austin, William, Neil C. McGinn and Charles Susmilch (1980). "Internal Standards Revisited: Effects of Social Comparisons and Expectancies on Judgments of Fairness and Satisfaction.” Journal of Experimental Social Psychology, 16, pp. 426-441.

Ball, Laurence S. (2000). "Near-Rationality and Inflation in Two Monetary Regimes." NBER Working Paper 7988.

and Mankiw, N. Gregory (1995). "Relative-Price Changes as Aggregate Supply Shocks." Quarterly Journal of Economics, CV:2, pp. 161-193.

Bernanke, Ben S. and Ilian Mihov (1998). "Measuring Monetary Policy." Quarterly Journal of Economics, CVIII:3, pp. 869-902.

Bhaskar, V. (1990). "Wage relatives and the natural range of unemployment." Economic Journal 100, 60-66.

Blanchard, Olivier J. and Nobuhiro Kiyotaki (1985). "Monopolistic competition and the effects of aggregate demand." American Economic Review, pp. 647-667.

Binmore, Ken., Ariel Rubinstein, and Asher Wolinsky (1986).'The Nash bargaining solution in economic modelling." RAND Journal of Economics, 17, pp176-188.

Bårdsen, G., E. Jansen and R. Nymoen (2002). "Testing the New-Keynesian Phillips Curve", Mimeo, University of Oslo.

Calvo, Guillermo (1983). "Staggered Prices in a Utility-Maximizing Framework." Journal of Monetary Economics 12:4, pp. 983-998.

Cooper, Russell W. (1999). Coordination Games: Complementarities and Macroeconomics. Cambridge University Press.

Danthine, Jean-Pierre and Andre Kurmann. "Fair Wages in a New Keynesian Model of the Business Cycle." Mimeo, University of Virginia.

Evans, George W. and Seppo Honkaphohja (2001). Learning and Expectations in Macroeconomics. Princeton: Princeton University Press.

Fehr, E. and K. M. Schmidt. (1999).A Theory of Fairness, Competition, and Cooperation. Quarterly Journal of Economics CXIV, pp. 769-816. 
Fischer, Stanley. (1977). "Long-Term Contracts, Rational Expectations, and the Optimal Money Supply Rule.” Journal of Political Economy 85:2, pp. 191-205.

Friedman, Milton (1968). "The Role of Monetary Policy." American Economic Review, 58:1, pp. 1-17.

Fuhrer, Jeffrey and Gerald Moore (1995). "Inflation persistence.” Quarterly Journal of Economics,CX, pp. 127-160.

Gali, Jordi and Mark Gertler (1999). "Inflation Dynamics: A Structural Econometric Analysis.” Journal of Monetary Economics 44, 195-222.

Goeree, J.K and C. A Holt. "Asymmetric Inequality Aversion and Noisy Behavior in Alternating-Offer Bargaining." European Economic Review 44, pp. 1079-1089.

Gordon, Robert J. (1990). "What is New-Keynesian Economics?" Journal of Economic Literature, XXVIII:3, pp. 1115-1171.

Kahneman, Daniel and Amos Tversky (1979). "Prospect Theory: An Analysis of Decision under Risk.” Econometrica, 47, pp 263-291.

Loewenstein, George F., Leigh Thompson, and Max H. Bazerman. (1989). Social Utility and Decision Making in Intermpersonal Contexts. " Journal of Personality and Social Psychology LVII, pp 426-441.

Lye, I, I. M. McDonald and H. Sibly (2001). "An Estimate of the Range of Equilibrium Rates of Unemployment for Australia." Economic-Record 77, 35-50.

Maddala, G. S. and In-Moo Kim (1998). Unit Roots, Cointegration and Structural Change. Cambridge University Press, Cambridge UK.

Mankiw, N. Gregory (2001). "The Inexorable and Mysterious Tradeoff Between Inflation and Unemployment." Economic Journal 111. C45-61.

McDonald, Ian (1995). "Models of the range of equilibria." In Rod Cross (ed). The Natural Rate of Unemployment: Reflections on 25 years of the hypothesis. Cambridge: Cambridge University Press.

McDonald, Ian (2001). "Reference Pricing, Inflation Targeting and the Non-inflationary Expansion.” Mimeo, University of Melbourne.

Ochs, Jack (1995). “Coordination Problems”. In John H. Kagen and Alvin Roth (eds). Handbook of Experimental Economics. Princeton: Princeton University Press. 
Ordonez, Lisa D., Terry Connolly and Richard Coughlan (2000). "Multiple Reference Points in Satisfaction and Fairness Assessment." Journal of Behavioral Decision Making, 13, pp. 329-244.

Phillips, A. W. (1959). "The Relation Between Unemployment and the Rate of Change of Money Wages in the United Kingdom 1861-1957." Economica, 25:2, pp. 283-299.

Quandt, Richard E. (1958). "The Estimation of the Parameters of a Linear Regression System Obeying Two Separate Regimes." Journal of the American Statistical Association, pp. 873-880.

Roberts, John. (1998). Inflation expectations and the transmission of monetary policy. Board of Governors of the Federal Reserve System.

Sbordone, Argia M. (2002). "Prices and Unit Labor Costs: A New Test of Price Stickiness." Journal of Monetary Economics, 49(2), pp. 265-292.

Shimer, Robert (1998). "Why is the U.S. Unemployment Rate So Much Lower?" NBER Macroeconomics Annual, pp. 11-61.

Sims, Christopher A. (1992). "Interpreting the Macroeconomic Time Series Facts: The Effects of Monetary Policy." European Economic Review, 36(4), pp. 975-1011.

Staiger, Douglas, James Stock and Mark Watson (1997). "How Precise Are Estimates of the Natural Rate of Unemployment?" In Christina D. Romer and David H. Romer (eds). Reducing Inflation: Motivation and Strategy, Chicago University Press.

----------- (2001). "Prices, Wages and the U.S. NAIRU in the 1990s". Mimeo, Kennedy School of Government, Harvard University.

Taylor, John. (1980). "Aggregate dynamics and staggered contracts." Journal of Political Economy LXXXVIII, 1-24.

(1999). "Staggered wage and price setting in macroeconomics." Chapter 15 in J. B. Taylor and M. Woodford (eds). Handbook of Macroeconomics. North-Holland.

Woglom, Geoffrey (1982). "Underemployment Equilibrium with Rational Expectations." Quarterly Journal of Economics 9, 89-107. 


\section{Appendix}

\section{Proof of Proposition 1}

Using

$$
\frac{d \Pi_{j t}}{d X_{j t}}=(1-\eta) \frac{\Pi_{j t}}{X_{j t}} \text { and } \quad \frac{d V}{d X_{j t}}=\frac{\left(1+\alpha+D_{j t} \phi\right) V_{j t}}{X_{j t}}
$$

(8) and (9) can be rewritten as

$$
\begin{aligned}
& (2+\alpha+\phi+\lambda-\eta) V_{j t}+(\eta-1) V_{0 t} \geq 0 \\
& (2+\alpha+\lambda-\eta) V_{j t}+(\eta-1) V_{0 t} \leq 0
\end{aligned}
$$

Substituting out for $\mathrm{V}_{\mathrm{jt}}$ using (4), imposing equality, (26) and (27) can be solved for

$$
X_{t}^{-}=\left(\frac{\eta-1}{\eta-2-\alpha-\phi-\lambda} V_{0 t} P_{t} X_{J t}^{\alpha+\phi} X_{G t}{ }^{\lambda}\right)^{\frac{1}{1+\alpha+\phi+\lambda}}
$$

and

$$
X_{t}^{+}=\left(\frac{\eta-1}{\eta-2-\alpha-\lambda} V_{0 t} P_{t} X_{J t}^{\alpha} X_{G t}^{\lambda}\right)^{\frac{1}{1+\alpha+\lambda}}
$$

To see that $\mathrm{X}^{-}\left(\mathrm{X}_{\mathrm{Jt}}, \mathrm{X}_{\mathrm{Gt}}, \mathrm{Y}_{\mathrm{t}}, \mathrm{P}_{\mathrm{t}}\right)>\mathrm{X}^{+}\left(\mathrm{X}_{\mathrm{Jt}}, \mathrm{X}_{\mathrm{Gt}}, \mathrm{Y}_{\mathrm{t}}, \mathrm{P}_{\mathrm{t}}\right)$, note that from imposing equality in (26) and (27), we obtain

$$
(\eta-2-\alpha-\phi-\lambda) V_{j t}\left(X^{-}{ }_{t}\right)=(\eta-1) V_{0 t}=(\eta-2-\alpha-\lambda) V_{j t}\left(X^{+}{ }_{t}\right)
$$

or

$$
\frac{V_{j t}\left(X^{-}{ }_{t}\right)}{V_{j t}\left(X^{+}{ }_{t}\right)}=\frac{\eta-2-\alpha-\lambda}{\eta-2-\alpha-\phi-\lambda} \Rightarrow X^{-}{ }_{t}>X^{+}{ }_{t} \text { as } \mathrm{V} \text { is increasing in } \mathrm{X} \text {. }
$$

To conclude, we know that either $\mathrm{X}_{\mathrm{jt}}=\mathrm{X}_{\mathrm{Jt}}$, and (8) and (9) both hold, so that $\mathrm{X}_{\mathrm{t}}^{-} \geq \mathrm{X}_{\mathrm{jt}} \geq \mathrm{X}_{\mathrm{t}}^{+}$, or (8) holds with equality, in which case $X_{j t}=X_{t}^{-}$, or (9) holds with equality, in which case $X_{j t}=X^{+}$. 


\section{Derivation of (10) and (11)}

Using the same procedure as in the proof of Proposition 1, (8) and (9) can be rearranged to

$$
X_{j t} \leq\left(\frac{\eta-1}{\eta-2-\alpha-\phi-\lambda} V_{0 t} P_{t} X_{J t}^{\alpha+\phi} X_{G t}^{\lambda}\right)^{\frac{1}{1+\alpha+\phi+\lambda}}
$$

and

$$
X_{j t} \geq\left(\frac{\eta-1}{\eta-2-\alpha-\lambda} V_{0 t} P_{t} X_{J t}^{\alpha} X_{G t}^{\lambda}\right)^{\frac{1}{1+\alpha+\lambda}}
$$

Imposing $\mathrm{X}_{\mathrm{jt}}=\mathrm{X}_{\mathrm{Jt}}$ and $\mathrm{P}_{\mathrm{t}}=\mu\left(\mathrm{X}_{\mathrm{Jt}}\right)^{1 / 2}\left(\mathrm{X}_{\mathrm{Gt}}\right)^{1 / 2}$, and rearranging, we obtain

$$
X_{J t} \leq X_{G t}\left(\frac{(\eta-1) \mu}{\eta-2-\alpha-\phi-\lambda} V_{0}\left(Y_{t}\right)\right)^{\frac{1}{1 / 2+\lambda}} .
$$

$$
X_{J t} \geq X_{G t}\left(\frac{(\eta-1) \mu}{\eta-2-\alpha-\lambda} V_{0}\left(Y_{t}\right)\right)^{\frac{1}{1 / 2+\lambda}} .
$$

Using the log linear approximations

$$
\begin{aligned}
& -\theta^{-}+\frac{\gamma_{0}}{2} y_{t} \equiv \ln \left(\frac{(\eta-1) \mu}{\eta-2-\alpha-\phi-\lambda} V_{0}\left(Y_{t}\right)\right)^{\frac{1}{1 / 2+\lambda}} . \\
& -\theta^{+}+\frac{\gamma_{0}}{2} y_{t} \equiv \ln \left(\frac{(\eta-1) \mu}{\eta-2-\alpha-\lambda} V_{0}\left(Y_{t}\right)\right)^{\frac{1}{1 / 2+\lambda}} .
\end{aligned}
$$

we obtain (10) and (11) in the main text 


\section{Table 1}

Phillips Curve Regressions, Quarterly Data, 1955:I-2000:IV

\begin{tabular}{|c|c|c|c|c|c|c|c|}
\hline \multicolumn{8}{|c|}{ Dependent Variable: $\pi_{\mathrm{t}}$} \\
\hline \multicolumn{2}{|c|}{ Without Bounds } & \multicolumn{6}{|c|}{ With Bounds } \\
\hline Const. & $\begin{array}{c}1.268^{* *} \\
(.428)\end{array}$ & Const. & $\begin{array}{c}2.956 \\
(1.827)\end{array}$ & $\mathrm{I}_{\mathrm{L}}{ }^{*}$ Const. & $\begin{array}{c}.646 \\
(.627)\end{array}$ & $\mathrm{I}_{\mathrm{H}} *$ Const. & $\begin{array}{c}1.766^{* *} * \\
(.585)\end{array}$ \\
\hline$\pi_{\mathrm{t}-1}$ & $\begin{array}{l}.510 * * \\
(.070)\end{array}$ & $\pi_{\mathrm{t}-1}$ & $\begin{array}{l}.438 * * \\
(.127)\end{array}$ & $\mathrm{I}_{\mathrm{L}} * \pi_{\mathrm{t}-1}$ & $\begin{array}{l}-.114 \\
(.272)\end{array}$ & $\mathrm{I}_{\mathrm{H}} * \pi_{\mathrm{t}-1}$ & $\begin{array}{l}-.083 \\
(.156)\end{array}$ \\
\hline$\pi_{\mathrm{t}-2}$ & $\begin{array}{l}.111 \\
(.079)\end{array}$ & $\pi_{\mathrm{t}-2}$ & $\begin{array}{l}.348^{* *} \\
(.123)\end{array}$ & $\mathrm{I}_{\mathrm{L}} * \pi_{\mathrm{t}-2}$ & $\begin{array}{l}-.363 \\
(.275)\end{array}$ & $\mathrm{I}_{\mathrm{H}} * \pi_{\mathrm{t}-2}$ & $\begin{array}{l}-.387^{*} \\
(.163)\end{array}$ \\
\hline$\pi_{\mathrm{t}-3}$ & $\begin{array}{c}-.384 * * \\
(.067)\end{array}$ & $\pi_{\mathrm{t}-3}$ & $\begin{array}{l}.413 * * \\
(.130)\end{array}$ & $\mathrm{I}_{\mathrm{L}} * \pi_{\mathrm{t}-3}$ & $\begin{array}{l}-.297 \\
(.247)\end{array}$ & $\mathrm{I}_{\mathrm{H}} * \pi_{\mathrm{t}-3}$ & $\begin{array}{l}.018 \\
(.151)\end{array}$ \\
\hline $\mathrm{u}_{\mathrm{t}-1}$ & $\begin{array}{c}-1.821^{* *} \\
(.314)\end{array}$ & $\mathrm{u}_{\mathrm{t}-1}$ & $\begin{array}{c}-1.967 * * \\
(.532)\end{array}$ & $\mathrm{I}_{\mathrm{L}} *\left(\mathrm{u}_{\mathrm{t}-1}-\mathrm{u}_{\mathrm{L}}\right)$ & $\begin{array}{c}.857 \\
(1.46)\end{array}$ & $\mathrm{I}_{\mathrm{H}} *\left(\mathrm{u}_{\mathrm{t}-1}-\mathrm{u}_{\mathrm{H}}\right)$ & $\begin{array}{l}.363 \\
(.689)\end{array}$ \\
\hline $\mathrm{u}_{\mathrm{t}-2}$ & $\begin{array}{c}1.608 * * \\
(.306)\end{array}$ & $\mathrm{u}_{\mathrm{t}-2}$ & $\begin{array}{c}1.358 * * \\
(.422)\end{array}$ & $\mathrm{I}_{\mathrm{L}} *\left(\mathrm{u}_{\mathrm{t}-2}-\mathrm{u}_{\mathrm{L}}\right)$ & $\begin{array}{l}-2.23 \\
(1.46)\end{array}$ & $\mathrm{I}_{\mathrm{H}} *\left(\mathrm{u}_{\mathrm{t}-2}-\mathrm{u}_{\mathrm{H}}\right)$ & $\begin{array}{l}.225 \\
(.590)\end{array}$ \\
\hline Food & $\begin{array}{l}.046^{* *} \\
(.015)\end{array}$ & Food & $\begin{array}{l}.042^{*} \\
(.020)\end{array}$ & $\mathrm{I}_{\mathrm{L}} *$ Food & $\begin{array}{l}.030 \\
(.043)\end{array}$ & $\mathrm{I}_{\mathrm{H}} *$ Food & $\begin{array}{l}.000 \\
(.033)\end{array}$ \\
\hline Fuel & $\begin{array}{c}.011 \\
(.009)\end{array}$ & Fuel & $\begin{array}{l}-.005 \\
(.013)\end{array}$ & $\mathrm{I}_{\mathrm{L}} *$ Fuel & $\begin{array}{l}.015 \\
(.021)\end{array}$ & $\mathrm{I}_{\mathrm{H}} *$ Fuel & $\begin{array}{l}.032 \\
(.020)\end{array}$ \\
\hline Nixon & $\begin{array}{c}1.807 \\
(2.889) \\
\end{array}$ & Nixon & $\begin{array}{c}-.498 \\
(2.851) \\
\end{array}$ & & & & \\
\hline Sum on & $1.004 * *$ & & $1.198 * *$ & & $-.775 * *$ & & $-.453 * *$ \\
\hline inflation & $(.040)$ & & $(.0526)$ & & $(.227)$ & & $(.083)$ \\
\hline Sum on & $-.213 * *$ & & -.608 & & -1.378 & & .587 \\
\hline unemp. & $(.073)$ & & $(.332)$ & & $(.907)$ & & $(.374)$ \\
\hline Bounds & N/A & & & $\mathrm{u}_{\mathrm{L}}$ & 4.7 & $\mathrm{u}_{\mathrm{H}}$ & 6.5 \\
\hline Adjusted $\mathrm{R}^{2}$ & .810 & & & & & & \\
\hline $\log \mathrm{L}$ & -311.30 & & & -286 & $* *$ & & \\
\hline \# Obs. & 184 & & & & & & \\
\hline
\end{tabular}

Note: Inflation is measured by the (annualized) quarterly percent change in the seasonallyadjusted CPI for all urban consumers. The unemployment rate is that for all civilians over age 16. 'Food' is the relative PPI inflation rate for processed foods and feeds, and 'Fuel' is the relative inflation rate for energy, both lagged one period. 'Nixon' is a dummy for wage and price controls due to Gordon (1990). $I_{H}$ and $I_{L}$ are dummy variables for periods when lagged unemployment is outside the bounds $u_{H}$ and $u_{L}$ described in the text. Thus, the total effect of the RHS variables below (above) the bound, is given by the sum of the coefficient between bounds and the coefficient below (above) bounds.

* Denotes statistical significance at the $5 \%$ level

** Denotes statistical significance at the $1 \%$ level 
Table 2

Phillips Curve Regressions, 1955:I-2000:IV

With Monetary Policy Indicator

\begin{tabular}{|c|c|c|c|c|c|c|c|}
\hline \multicolumn{8}{|c|}{ Dependent Variable: $\pi_{\mathrm{t}}$} \\
\hline \multirow{2}{*}{\multicolumn{2}{|c|}{ Without Bounds }} & \multicolumn{6}{|c|}{ With Bounds } \\
\hline & & \multicolumn{2}{|c|}{ Between Bounds } & \multicolumn{2}{|c|}{ Below Bound } & \multicolumn{2}{|c|}{ Above Bound } \\
\hline Const. & $\begin{array}{l}1.125^{*} \\
(.498)\end{array}$ & Const. & $\begin{array}{c}1.690 \\
(1.868)\end{array}$ & $\mathrm{I}_{\mathrm{L}} *$ Const. & $\begin{array}{c}.785 \\
(.685)\end{array}$ & $\mathrm{I}_{\mathrm{H}} *$ Const. & $\begin{array}{l}1.190 \\
(.645)\end{array}$ \\
\hline$\pi_{\mathrm{t}-1}$ & $\begin{array}{l}.442 * * \\
(.068)\end{array}$ & $\pi_{\mathrm{t}-1}$ & $\begin{array}{l}.341^{*} \\
(.131)\end{array}$ & $\mathrm{I}_{\mathrm{L}} * \pi_{\mathrm{t}-1}$ & $\begin{array}{l}-.011 \\
(.274)\end{array}$ & $\mathrm{I}_{\mathrm{H}} * \pi_{\mathrm{t}-1}$ & $\begin{array}{l}.020 \\
(.160)\end{array}$ \\
\hline$\pi_{\mathrm{t}-2}$ & $\begin{array}{l}.048 \\
(.077)\end{array}$ & $\pi_{\mathrm{t}-2}$ & $\begin{array}{l}.352 * * \\
(.125)\end{array}$ & $\mathrm{I}_{\mathrm{L}} * \pi_{\mathrm{t}-2}$ & $\begin{array}{l}-.351 \\
(.275)\end{array}$ & $\mathrm{I}_{\mathrm{H}} * \pi_{\mathrm{t}-2}$ & $\begin{array}{c}-.446 * * \\
(.165)\end{array}$ \\
\hline$\pi_{\mathrm{t}-3}$ & $\begin{array}{l}.388 * * \\
(.063)\end{array}$ & $\pi_{\mathrm{t}-3}$ & $\begin{array}{l}.459 * * \\
(.128)\end{array}$ & $\mathrm{I}_{\mathrm{L}} * \pi_{\mathrm{t}-3}$ & $\begin{array}{l}-.359 \\
(.242)\end{array}$ & $\mathrm{I}_{\mathrm{H}} * \pi_{\mathrm{t}-3}$ & $\begin{array}{l}-.061 \\
(.150)\end{array}$ \\
\hline $\mathrm{u}_{\mathrm{t}-1}$ & $\begin{array}{c}-1.531 * * \\
(.324)\end{array}$ & $\mathrm{u}_{\mathrm{t}-1}$ & $\begin{array}{c}-1.479 * * \\
(.573)\end{array}$ & $\mathrm{I}_{\mathrm{L}} *\left(\mathrm{u}_{\mathrm{t}-1}-\mathrm{u}_{\mathrm{L}}\right)$ & $\begin{array}{c}.544 \\
(1.525)\end{array}$ & $\mathrm{I}_{\mathrm{H}} *\left(\mathrm{u}_{\left.\mathrm{t}-1-\mathrm{u}_{\mathrm{H}}\right)}\right.$ & $\begin{array}{l}.118 \\
(.731)\end{array}$ \\
\hline $\mathrm{u}_{\mathrm{t}-2}$ & $\begin{array}{c}1.354 * * \\
(.299)\end{array}$ & $\mathrm{u}_{\mathrm{t}-2}$ & $\begin{array}{c}1.127 * * \\
(.431)\end{array}$ & $\mathrm{I}_{\mathrm{L}} *\left(\mathrm{u}_{\mathrm{t}-1}-\mathrm{u}_{\mathrm{L}}\right)$ & $\begin{array}{l}-1.817 \\
(1.502)\end{array}$ & $\mathrm{I}_{\mathrm{H}} *\left(\mathrm{u}_{\mathrm{t}-2}-\mathrm{u}_{\mathrm{H}}\right)$ & $\begin{array}{l}.111 \\
(.596)\end{array}$ \\
\hline Food & $\begin{array}{l}.036^{*} \\
(.015)\end{array}$ & Food & $\begin{array}{l}.043^{*} \\
(.019)\end{array}$ & $\mathrm{I}_{\mathrm{L}} *$ Food & $\begin{array}{l}.024 \\
(.044)\end{array}$ & $\mathrm{I}_{\mathrm{H}} *$ Food & $\begin{array}{l}-.004 \\
(.033)\end{array}$ \\
\hline Fuel & $\begin{array}{l}.001 \\
(.001)\end{array}$ & Fuel & $\begin{array}{l}.001 \\
(.013)\end{array}$ & $\mathrm{I}_{\mathrm{L}} *$ Fuel & $\begin{array}{l}.012 \\
(.021)\end{array}$ & $\mathrm{I}_{\mathrm{H}} *$ Fuel & $\begin{array}{l}.027 \\
(.020)\end{array}$ \\
\hline Nixon & $\begin{array}{c}.181 \\
(2.776)\end{array}$ & Nixon & $\begin{array}{c}-.010 \\
(3.068)\end{array}$ & & N/A & & N/A \\
\hline $\begin{array}{l}\text { Monetary } \\
\text { Expansion }\end{array}$ & $\begin{array}{l}.0774 \\
(.060)\end{array}$ & $\begin{array}{l}\text { Monetary } \\
\text { Expansion }\end{array}$ & $\begin{array}{l}-.205 \\
(.127)\end{array}$ & & $\begin{array}{c}.556 \\
(.712)\end{array}$ & & $\begin{array}{l}.335^{*} \\
(.154)\end{array}$ \\
\hline $\begin{array}{l}\text { Monetary } \\
\text { Contraction }\end{array}$ & $\begin{array}{c}-.254 * * \\
(.057)\end{array}$ & $\begin{array}{c}\text { Monetary } \\
\text { Contraction }\end{array}$ & $\begin{array}{l}-.063 \\
(.077)\end{array}$ & & $\begin{array}{l}-.017 \\
(.197)\end{array}$ & & $\begin{array}{c}-.595 * * \\
(.222)\end{array}$ \\
\hline $\begin{array}{l}\text { Sum on } \\
\text { inflation }\end{array}$ & $\begin{array}{l}.877 * * \\
(.049)\end{array}$ & & $\begin{array}{c}1.152 * * \\
(.072)\end{array}$ & & $\begin{array}{l}-.721 * * \\
(.252)\end{array}$ & & $\begin{array}{c}-.487 * * \\
(.103)\end{array}$ \\
\hline $\begin{array}{l}\text { Sum on } \\
\text { unemp. }\end{array}$ & $\begin{array}{l}-.176 \\
(.097)\end{array}$ & & $\begin{array}{l}-.351 \\
(.343)\end{array}$ & & $\begin{array}{l}-1.273 \\
(1.085)\end{array}$ & & $\begin{array}{c}.228 \\
(.403)\end{array}$ \\
\hline Bounds & $\mathrm{N} / \mathrm{A}$ & & & $\mathrm{u}_{\mathrm{L}}$ & 4.7 & $\mathrm{u}_{\mathrm{H}}$ & 6.5 \\
\hline $\begin{array}{c}\text { Adjusted } \\
\mathrm{R}^{2} \\
\text { LogL } \\
\text { \# Obs. } \\
\end{array}$ & $\begin{array}{c}.828 \\
-301.32 \\
184\end{array}$ & & & $\begin{array}{r}8 \\
-276 . \\
18\end{array}$ & & & \\
\hline
\end{tabular}

Note: 'Monetary Contractions' represents the value of the Bernanke and Mihov (1998) indicator for monetary policy when that indicator is negative, and 'Monetary Expansions' the value of that indicator when the indicator is positive. All other notation as in Table 1.

* Denotes statistical significance at the $5 \%$ level

** Denotes statistical significance at the $1 \%$ level 